\title{
Keanekaragaman Jenis Tegakan Hutan Adat Sona Kabupaten Sintang
}

\author{
Muhammad Syukur \\ Fakultas Pertanian Universitas Kapuas Sintang \\ Email : msyukur1973@yahoo.co.id
}

\begin{abstract}
Abstrak : Penelitian ini bertujuan untuk mengetahui keanekaragaman jenis tegakan yang terdapat pada kawasan Hutan Adat Sona Kabupaten Sintang. Penelitian ini dilaksanakan dengan menggunakan metode jalur/transek. Jalur dibuat dengan arah memotong kontur sebanyak 2 buah dengan panjang jalur masing-masing 500 meter. Pada setiap jalur dibuatkan petak pengamatan secara kontinyu dengan ukuran sesuai tingkat pertumbuhan, yaitu $2 \mathrm{~m}$ x $2 \mathrm{~m}$ untuk tingkat Semai, $5 \mathrm{~m}$ x $5 \mathrm{~m}$ untuk tingkat Pancang, $10 \mathrm{~m} \times 10 \mathrm{~m}$ untuk tingkat Tiang dan $20 \mathrm{~m}$ x $20 \mathrm{~m}$ untuk tingkat Pohon, dengan demikian luas total petak pengamatan adalah $2 \mathrm{Ha}$.

Hasil penelitian menunjukkan terdapat 22 jenis tegakan hutan, untuk tingkat semai secara berurutan jenis-jenis yang dominan adalah Medang Piawas (Litsea firma), Garu Engkaras (Aquilaria malaccensis), Terentang (Camnosperma auriculatum), Entangor (Callophylum soulattri) dan Engkerabang (Cratoxylon $s p$ ). Untuk tingkat pancang secara berurutan jenis-jenis yang dominan adalah Medang Piawas, Majau (Shorea spp), Garu Engkaras, Entangor dan Terentang. Untuk tingkat tiang secara berurutan jenis-jenis yang dominan adalah Medang Piawas, Entangor, Majau, Terentang dan Garu Engkaras, Untuk tingkat pohon secara berurutan jenis-jenis yang dominan adalah Medang Piawas, Entangor, Majau, Terentang dan Rengas (Melanorrea walichii). Keanekaragaman jenis tegakan hutan untuk tingkat semai, pancang, tiang dan pohon menurut kriteria Shannon-Wielner tergolong sedang dengan nilai indeks keanekaragaman jenis tingkat semai sebesar $\mathrm{H}=1,3043$, tingkat pancang sebesar $\mathrm{H}=1,2447$, tingkat tiang sebesar $\mathrm{H}=1,2467$ dan tingkat pohon indeks keanekaragaman jenis sebesar $\mathrm{H}=1,1801$.
\end{abstract}

Kata Kunci : Keanekaragaman Jenis Tegakan Hutan dan Hutan Adat Sona

\section{PENDAHULUAN}

Kelestarian hutan hujan tropika

di Indonesia berhubungan erat dengan penerapan prinsip-prinsip silvikultur. Kunci dari pelaksanaan prinsip kelestarian terletak pada suksesnya permudaan hutan.
Menurut Sakunto (1995), untuk menjaga kelestarian sumber daya hutan dan keserasian serta keseimbangan lingkungan hidup, pengelolaan sunber daya hutan harus didasarkan pada asas-asas ekologi dan pendekatan ekosistem. Berbagai 
metode silvikultur telah dicoba untuk menjaga kelestarian hutan agar sumber daya alam ini dapat diusahakan secara berkelanjutan. Namun bersamaan dengan itu, kerusakan dan berkurangnya potensi hutan juga terus bertambah baik terhadap ekosistem hutan maupun jumlah permudaan yang potensial untuk dikembangkan.

Tegakan (stand) adalah kesatuan pohon-pohon atau tumbuhan lain yang menempati suatu areal tertentu dan yang memiliki komposisi jenis, umur, dan kondisi yang cukup seragam untuk dapat dibedakan dari hutan atau kelompok tumbuhan lain. Menurut para ahli ekologi, tegakan hutan dibagi menjadi dua, yaitu tegakan seumur dan tegakan tidak seumur. Tegakan seumur (even-aged stand) adalah tegakan yang terdiri atas pohonpohon yang berumur sama atau paling tidak berada dalam kelas umur yang sama. Menurut MacKinnon, dkk (2000), suatu tegakan dianggap seumur kalau perbedaan umur antara pohon-pohon yang paling tua dan yang paling muda tidak melebihi 20\% panjang daur (rotasi).
Sebenarnya dalam hutan yang dipermudakan secara alami sukar sekali dijumpai tegakan yang terdiri dari pohon-pohon yang berumur sama. Oleh karena itu mungkin lebih tepat kalau katakan bahwa tegakan seumur adalah tegakan yang terdiri dari pohon-pohon dengan perbedaan umur antara pohon yang paling muda dan yang paling tua yang diperbolehkan adalah 10 sampai 20 tahun. Namun demikian, apabila tegakan tersebut tidak akan ditebang sebelum berumur 100 - 200 tahun, maka perbedaan umur yang diperbolehkan mencapai $25 \%$ dari umur daur atau rotasi. Tegakan tidak Seumur (uneven-aged stand) adalah tegakan yang terdiri dari pohonpohon dengan perbedaan umur antara pohon yang paling tua dengan pohon yang paling muda paling sedikit sebesar tiga kelas umur. Jadi dalam tegakan tidak seumur terdapat paling sedikit tiga kelas umur atau bahkan lebih yang dikenal dengan tingkat semai, pancang, tiang dan pohon.

Berbagai upaya telah dilakukan oleh pemerintah untuk menjaga kelestarian hutan, namun sampai saat ini hasilnya belum maksimal, karena 
area hutan terus mengalami degradasi oleh berbagai aktivitas manusia. Kelestarian kawasan hutan justru terlihat berhasil melalui kearifan lokal dalam bentuk hutan adat. Salah satu hutan adat yang terdapat di Kalimantan Barat Khususnya di Kabupaten Sintang adalah Hutan Adat Sona. Hutan Adat Sona adalah hutan yang terdapat di lahan Enclave kawasa perusahaan PT Wahana Plantation and Products. Sebagai hutan tropis tentu memiliki kenaekaragaman yang tinggi, tetapi secara faktual informasi mengenai jenis-jenis tegakan alam pada kawasan hutan tersebut masih belum tersedia, sehingga perlu dilakukan kajian sebagai langkah awal untuk menjaga kelestariannya.

\section{METODE PENELITIAN}

Penelitian ini dilaksanakan dengan menggunakan metode jalur/transek. Jalur dibuat dengan arah memotong kontur sebanyak 2 buah dengan panjang jalur masing-masing 500 meter. Pada setiap jalur dibuatkan petak pengamatan secara kontinyu dengan ukuran sesuai tingkat pertumbuhan, yaitu $2 \mathrm{~m}$ x $2 \mathrm{~m}$ untuk tingkat Semai, $5 \mathrm{~m}$ x $5 \mathrm{~m}$ untuk tingkat Pancang, $10 \mathrm{~m}$ x $10 \mathrm{~m}$ untuk tingkat Tiang dan $20 \mathrm{~m}$ x $20 \mathrm{~m}$ untuk tingkat Pohon, dengan demikian luas total petak pengamatan adalah $2 \mathrm{Ha}$. Setelah pembuatan petak pengamatan selesai, maka dilakukan analisa terhadap tegakan yang ada, yaitu mengidentifikasi dan inventarisasi seluruh jenis tumbuhan tingkat semai sampai tiang yang terdapat pada petak pengamatan. Data hasil penelitian dianalisis menggunakan persamaan Indeks Nilai Penting (INP), Indek Dominansi Jenis (C), Indeks Keanekaragaman Jenis Shannon $(\mathrm{H})$, dan Indeks Kelimpahan Jenis (e).

\section{HASIL DAN PEMBAHASAN}

\section{Hasil Penelitian}

Berdasarkan hasil penelitian pada kawasan Hutan Adat Sona Kabupaten Sintang diketahui bahwa, terdapat 22 jenis tegakan tingkat semai dengan jumlah individu sebanyak 471 individu. Untuk tingkat pancang, tiang dan pohon ditemukan sebanyak 19 jenis dengan rincian individu tingkat pancang sebanyak 340 individu, tingkat tiang 
sebanyak 238 individu dan tingkat pohon sebanyak 146 individu.

Untuk setiap tingkat pertumbuhan vegetasi jenis yang dominan relatif seragam, yaitu jenis Medang Piawas, Majau, Entangor, Engkerabang, Terentang, Garu Engkaras dan Rengas. Untuk tingkat semai secara berurutan jenis-jenis yang dominan adalah Medang Piawas, Garu Engkaras, Terentang, Entangor dan Engkerabang dengan keanekaragaman jenis menurut kriteria Shannon-Wielner tergolong sedang $(\mathrm{H}=1,3043)$. Untuk tingkat pancang secara berurutan jenis-jenis yang dominan adalah Medang Piawas, Majau, Garu Engkaras, Entangor dan Terentang, dengan keanekaragaman jenis menurut kriteria Shannon-
Wielner tergolong sedang $(\mathrm{H}=$ 1,2447). Untuk tingkat tiang secara berurutan jenis-jenis yang dominan adalah Medang Piawas, Entangor, Majau, Terentang dan Garu Engkaras, dengan keanekaragaman jenis menurut kriteria ShannonWielner tergolong sedang $(\mathrm{H}=$ 1,2467). Untuk tingkat pohon secara berurutan jenis-jenis yang dominan adalah Medang Piawas, Entangor, Majau, Terentang dan Rengas, dengan keanekaragaman jenis menurut kriteria ShannonWielner tergolong sedang $(\mathrm{H}=$ 1,1801).

Keanekargaman jenis tegakan yang terdapat pada kawasan hutan adat Sona Kabupaten Sintang.

Tabel 1. Daftar Jenis Tegakan Hutan Pada Hutan Adat Sona Desa Gandis Kecamatan Dedai Kabupaten Sintang

\begin{tabular}{|l|l|l|l|l|}
\hline No & Jenis & Nama Ilmiah & Genus & Famili \\
\hline 1 & Buntung & Cratoxylum spp & Cratoxylum & Hypericaceae \\
\hline 2 & Bunyau & Shorea $s p$ & Shorea & Dipterocarpaceae \\
\hline 3 & Engkerabang & Cratoxylon $s p$ & Cratoxylon & Guttiferae \\
\hline 4 & Entangor & Callophylum soulattri & Callophylum & Clusiaceae \\
\hline 5 & Gandis & Garcinia celebica & Garcinia & Guttiferae \\
\hline 6 & Garu Engkeras & Aquilaria malaccensis & Aquilaria & Thymeleaceae \\
\hline 7 & Gebidan & Octamales sp & Octamales & Apocynaceae \\
\hline 8 & Jelutung & Dyera costulata & Dyera & Apocynaceae \\
\hline 9 & Jengkol Tikus & Archidendron bubalinum & Archidendron & Fabaceae \\
\hline 10 & Kayu Irat & Diospyros bantamensis & Diospyros & Guttiferae \\
\hline
\end{tabular}


Keanekaragaman Jenis Tegakan Hutan Adat Sona

Kabupaten Sintang

\begin{tabular}{|l|l|l|l|l|}
\hline 11 & Kayu Abu & Lygodium circinatum & Lygodium & Schizaeaceae \\
\hline 12 & Keleban & Vitex pubescens & Vitex & Verbenaceae \\
\hline 13 & Kumpang & Myristica spp & Myristica & Mirysticaceae \\
\hline 14 & Lungkai & Chionanthus caudiforus & Chionanthus & Myrtaceae \\
\hline 15 & Majau & Shorea spp & Shorea spp & Dipterocarpaceae \\
\hline 16 & Medang Piawas & Litsea firma & Litsea firma & Lauraceae \\
\hline 17 & Merebung & Dactylocladus stenostachys & Dactylocladus & Melastomataceae \\
\hline 18 & Remayan & Knema sp & Knema sp & Mirysticaceae \\
\hline 19 & Rengas & Melanorrea walichii & Melanorrea & Anacardiacea \\
\hline 20 & Serantung & Arthocarpus sp & Arthocarpus & Moraceae \\
\hline 21 & Simpur & Dillenia excelsa (Jack) & Dillenia & Dilleniaceae \\
\hline 22 & Terentang & Camnosperma auriculatum & Camnosperma & Anacardiaceae \\
\hline
\end{tabular}

\section{Pembahasan}

Keanekaragaman jenis merupakan karakteristik ekologi yang dapat diukur dan khas untuk organisasi ekologi pada tingkat komunitas. Berdasarkan pengertian tersebut, maka keanekaragaman adalah jumlah total jenis dari berbagai macam organisme yang berbeda dalam suatu komunitas tertentu. keanekaragaman jenis merupakan karakteristik yang mencerminkan sifat organisasi yang penting dalam berfungsinya suatu komunitas. Keanekaragaman ditandai oleh banyaknya jenis yang membentuk suatu komunitas, semakin banyak jumlah jenis maka semakin tinggi keanekaragamannya. Keanekaragaman jenis dinyatakan dalam indeks keanekaragaman.
Indeks keanekaragaman menunjukkan hubungan antara jumlah jenis dengan jumlah individu yang menyusun suatu komunitas, nilai keanekaragaman yang tinggi menunjukkan lingkungan yang stabil sedangkan nilai keanekaragaman yang rendah menunjukkan lingkungan tidak stabil dan cenderung berubah ubah.

Keanekaragaman jenis merupakan suatu karakteristik tingkatan komunitas berdasarkan organisasi biologinya yang dapat digunakan untuk menyatakan struktur komunitas. Pemahaman ini dapat digunakan untuk mengukur kemampuan suatu komunitas pada habitat tertentu (adaptasi) dalam rangka menyeimbangkan komponen biotik dan abiotik dari berbagai 
gangguan. Hal ini juga dapat digunakan untuk menyatakan struktur komunitasnya. Suatu komunitas dikatakan mempunyai keanekaragaman yang tinggi jika komunitas tersebut disusun oleh banyak jenis dengan kelimpahan jenis sama dan hampir sama. Sebaliknya jka suatu komunitas disusun oleh sedikit jenis dan hanya sedikit jenis yang dominan maka keanekaragaman jenisnya rendah.

Keanekaragaman jenis dalam suatu komunitas dapat diukur, dengan menggunakan indeks keanekaragaman jenis Simpson dan indeks keanekaragaman jenis Shannon-Wielner. Indeks keanekaragaman jenis Simpson menunjukkan tingkat dominansi dalam suatu komunitas sedangkan Indeks keanekaragaman jenis Shannon-Wielner menunjukkan tingkat keanekaragaman dalam suatu komunitas. Semakin tinggi nilai indeks keanekaragaman jenis Simson, maka semakin tinggi tingkat dominansinya, sehingga semakin sedikit keanekaragamannya, begitu juga sebaliknya jika keanekaragaman jenis Shannon-Wielner tinggi, maka tidak ada jenis yang dominan dibandingkan dengan yang lainnya. Keanekaragaman jenis menurut Shannon dibagi menjadi tiga kategori yaitu :

$\mathrm{H}^{\prime}<1=$ keanekaragaman rendah $1<\mathrm{H}^{\prime}<3=$ keanekaragaman sedang $\mathrm{H}^{\prime}>3=$ keanekaragaman tinggi

Keanekaragaman jenis memiliki dua komponen utama yaitu kekayaan jenis (species richness) dan kelimpahan relatif (relative abundance). Keanekaragaman jenis dalam suatu komunitas sangat berkaitan dengan kelimpahan jenis tersebut dalam area tertentu. Keanekaragaman jenis pada suatu ekosistem berbeda beda dan dipengaruhi oleh berbagai faktor. Faktor yang mempengaruhi keanekaragaman jenis antara lain adalah:

1. Waktu. Keanekaragaman suatu komunitas lazimnya akan bertambah bersamaan dengan bertambahnya waktu. Hal ini memberikan makna bahwa, suatu komunitas yang sudah lama, akan lebih banyak terdapat organisme 
dari pada komunitas muda yang baru.

2. Heterogenitas Ruang. Ruang tempat tumbuh dan berkembang suatu komunitas yang tidak seragam, maka semakin kompleks komunitas flora dan fauna pada tempat tersebut dan biasanya akan semakin tinggi keanekaragaman jenisnya.

3. Kompetisi/Persaingan. Persaingan terjadi antara organisme dalam memperebutkan ruang, cahaya, air dan mineral. Ketersediaan ruang, cahaya, air dan mineral sangat menetukan keanekaragaman jenis pada suatu komunitas, bila hal ini tercukupi maka keanekaraghaman jenis akan tinggi begitu juga sebaliknya.

4. Pemangsaan/Peniadaan. Untuk mempertahankan diri pada suatu populasi dan komutias, maka setiap jenis akan bersaing untuk saling meniadakan walaupun terdapat juga adanya hubungan saling menguntungkan (simbiosis mutualisme). Apabila pemangsaan ini berada dibawah daya dukung masing masing jenis akan memperbesar kemunginan hidup secara berdampingan sehingga mempertinggi keanekaragaman. Apabila berada diatas daya dukung habitatnya, maka intensitas dari pemangsaan akan tinggi dan dapat menurunkan keanekaragaman jenis.

5. Produktifitas. Produktifitas suatu jenis adalah kemampuan setiap jenis untuk memperbanyak diri. Semakin tinggi produktifitas suatu jenis, maka akan semakin kuat kemampuanya untuk menguasai komunitas, sehingga keanekaragaman jenis akan rendah. Namun jika semua jenis memiliki kemampuan produktiftas yang relatif sama, maka keanekaragaman jenis akan tinggi.

Kelimpahan jenis adalah proporsi representasi oleh masing masing jenis dari seluruh individu dalam suatu komunitas atau dapat juga dinyatakan sebagai total seluruh individu dari semua jenis yang terdapat dalam komunitas. Berdasarkan pengertian tersebut, maka kelimpahan jenis adalah jumlah atau banyaknya individu dari seluruh jenis pada suatu area tertentu dalam suatu komunitas dan pada 
waktu tertentu pula. Kelimpahan jenis adalah jumlah atau banyaknya individu pada suatu area tertentu dalam suatu komunitas tertentu.

Beberapa jenis tegakan hutan berupa pohon yang terdapat pada kawasan hutan adat Sona memiliki nilai ekonomis tinggi, karena dapat digunakan untuk berabagai macam kebutuhan seperti perabot rumah tangga maupun bahan bangunan/konstruksi rumah. Semakin sempit/terbatasnya luas hutan dan sulitnya mendapat kayu, menimbulkan kekhawatiran akan terjarahnya kawasan hutan adat ini. Penguatan kelembagaan adat adalah modal terbesar untuk menjaga dan menjamin kelestarian kawasan, sekaligus menjamin kelestarian keanekaragaman jenis tegakan hutan yang sulit dijumpai pada saat sekarang ini, oleh karena berbagai upaya pemanfaatan lahan seperti perkebunan, konversi lahan, pertambangan dan lain sebagainya.

\section{PENUTUP}

\section{Kesimpulan}

Berdasarkan hasil penelitian dan pengamatan, maka dapat disimpulkan sebagai berikut;

1. Secara keseluruhan terdapat 22 jenis tegakan hutan, untuk tingkat semai secara berurutan jenis-jenis yang dominan adalah Medang Piawas (Litsea firma), Garu Engkaras (Aquilaria malaccensis), Terentang

(Camnosperma auriculatum), Entangor (Callophylum soulattri) dan Engkerabang (Cratoxylon sp). Untuk tingkat pancang secara berurutan jenis-jenis yang dominan adalah Medang Piawas, Majau (Shorea spp), Garu Engkaras, Entangor dan Terentang. Untuk tingkat tiang secara berurutan jenis-jenis yang dominan adalah Medang Piawas, Entangor, Majau, Terentang dan Garu Engkaras, Untuk tingkat pohon secara berurutan jenisjenis yang dominan adalah Medang Piawas, Entangor, Majau, Terentang dan Rengas (Melanorrea walichii).

2. Keanekaragaman jenis tegakan hutan untuk tingkat semai, 
pancang, tiang dan pohon menurut kriteria Shannon-Wielner tergolong sedang dengan nilai indeks keanekaragaman jenis tingkat semai sebesar $\mathrm{H}=1,3043$, tingkat pancang sebesar $\mathrm{H}=$ 1,2447, tingkat tiang sebesar $\mathrm{H}=$ 1,2467 dan tingkat pohon indeks keanekaragaman jenis sebesar $\mathrm{H}=$ 1,1801 .

\section{Saran}

Kawasan hutan adat Sona adalah satu satunya kawasan hutan yang tersisa diantara perkebunan Kelapa Sawit. Oleh karena itu kawasan ini harus terus dipertahankan baik melalui penguatan kelembagaan adat maupun campur tangan pemerintah untuk memperkuat status legalitas kawasan, sehingga dapat terjamin kelesatrain fungsi kawasan dan dapat menjadi sumber plasma nutfah keanekaragaman hayati pohon hutan.

\section{DAFTAR PUSTAKA}

Darwo. 2014. Sintesa Hasil PenelitianPengelolaan

Hutan Alam Produksi Lestari. Pusat Penelitian Dan Pengembangan Peningkatan Produktivitas Hutan Badan Penelitian Dan Pengembangan Kehutanan.
Kementerian Kehutanan Republik Indonesia.

Ewuise, J.Y. 1990. Pengantar Ekologi Hutan Tropika. Terjemahan Usman Tanujaya. Institut Teknologi Bandung.

MacKinnon, Gusti Hatta, Hakimah Halim dan Arthur Mangalik. 2000. Ekologi Kalimantan. Seri ekologi Indonesia Buku III. Prenhallindo. Jakarta.

Manan, S. 1997. Hutan Rimbawan Dan Masyarakat. Institut Pertanian Bogor Press. Bogor.

Odum, E.P. 1993. Dasar-Dasar Ekologi. Terjemahan Tjahojono Samingan, Edisi Ketiga Gajah Mada oleh Universitas Press, Yogyakarta.

Sakunto. 1995. Ekonomi Kehutanan Ekologi dan Pengelolaan Sumber Daya Hutan. Pontianak: Departemen Pendidikan dan Kebudayan, Fakultas Pertanian Universitas Tanjungpura Pontianak.

Soerianegara, I. dan Indrawan, A. 2005. Ekologi Hutan Indonesia. Bogor: Fakultas Kehutanan IPB.

Soerjani, M. 1992. Melestarikan Hutan Tropika. Jakarta: Yayasan Obor Indonesia.

Surati Jaya I N, Samsuri, Lastini T, dan Purnama E.S. 2010. 
Keanekaragaman Jenis Tegakan Hutan Adat Sona Kabupaten Sintang

\author{
Teknik Inventarisasi \\ Sediaan Ramin Di Hutan \\ Rawa Gambut (Inventory \\ Technique Of Ramin In Peat \\ Swamp Forest). Itto Cites \\ Project Bekerjasama \\ Dengan Pusat Penelitian \\ Dan Pengembangan Hutan \\ Dan Konservasi Alam \\ Badan Penelitian Dan \\ Pengembangan Kehutanan \\ Kementerian Kehutanan. \\ Bogor.
}


